\section{Frontier Jerusalem: The Holy Land as a Testing Ground for Urban Design}

Alona Nitzan-Shiftan
In 1969, a couple of years after Israel seized East Jerusalem from Jordan, seventy of the world's leading writers, philosophers, theologians, artists, architects, and urban planners accepted Mayor Teddy Kollek's invitation to join the Jerusalem Committee, an international urban think tank that would supervise Israel's unilateral unification of the city. According to architect Moshe Safdie, "such figures as Louis I. Kahn, Buckminster Fuller, Sir Nicholas Pevsner, Bruno Zevi, Lewis Mumford, Dennys Lasdun and Lawrence Halprin" agreed to donate their time because of "the aura of Jerusalem and the Mayor's personal commitment." ${ }^{-}$ There was, however, an even more compelling reason: Jerusalem offered an irresistible testing ground for a discipline in crisis.

The Western concept of urban beauty as an objective of modern planning had been established in Jerusalem by the British Mandate's colonial regime. Its commitment to the "visual idea" of Jerusalem emanated from a Western imagination linking the city's Orientalist physical beauty to its spiritual virtuousness. Escaping contemporary Euro-American urban renewal, inner-city highways, and sprawling suburbia, late-twentieth-century architects sought in Jerusalem's Orientalist authenticity salvation from a familiar and ubiquitous modernity. Israel represented a new frontier, an opportunity to gain what the West had already lost: the production of "the first 2oth-century urban place." ${ }^{2}$

Lewis Mumford, the famed author of The Culture of Cities, also wrote Kollek. Long disillusioned with the modern movement's approach to cities, Mumford believed its advocacy of order, zoning, and scientific urban form accelerated rather than ameliorated the fragmentation of the metropolis. Hence he sought in Jerusalem, in "its [indisputable] presence and person," the key for a renewed sense of urban unity which, "[d]espite all present 
divisions and antagonisms," could be found in "the structure of the city, its topography, its soil, its ancient walls, its historic sites." Mumford confessed, "I feel that in Jerusalem not merely the fate of Israel, but the destiny of the world in the centuries to come may actually be at stake."3

The salient questions for Mumford and his colleagues were these: How can cities become and/or remain identifiable entities manifesting distinct personae? How can a city's spatial and material presence alleviate the alienation associated with modern urban life? Their decade-long preoccupation with these issues had given rise to the nascent discipline of urban design. Charging Jerusalem with the mission to safeguard the "presence and character" of an exemplary city via modern development, architects and planners turned the newly unified city into their testing ground for the new discipline.

Urban design promised to take into account the efficient, sustainable, and profitable city that modern architects and planners envisioned without neglecting the emotional, aesthetic, and symbolic needs of individuals and communities that modernists allegedly ignored. Thus they focused attention on the urban place as a locus of formal, spatial, and social identity. Places would induce a feeling of belonging and social connectedness, urban designers argued, only if professionals addressed specific human senses in three-dimensional spaces. This approach demanded new skills rooted in design methodology and encouraged architects to return to the rudimentary functions of their discipline-designing form, space, light, and movement — while imbuing their aesthetics with moral conviction.

The Mamilla neighborhood provided an excellent case study. Located at the top of the Hinnom Valley next to the Jaffa Gate-a main entrance to the ancient Old City-it had been Jerusalem's most vital commercial district during the British Mandate. The 1949 armistice cut off Mamilla from East Jerusalem and the Old City, which were awarded to Jordan, leading to degeneration into a dilapidated neighborhood of small businesses and autorepair shops. In 1965, the Israeli government signaled its intention to rehabilitate Mamilla's 28 acres with an architectural competition. ${ }^{4}$ A bird's-eye view of the winning proposal, by Michael Kuhn, reveals an array of modernist forms - low- and high-rise, neatly designed rectangular buildings - arranged along a main thoroughfare with elevated walkways and separate traffic systems for pedestrians and vehicles. The main street spans the valley leading to the Old City, whose silhouette skims the sky. ${ }^{5}$

Kuhn's proposal came under attack soon after the war ended. National officials wanted the Mamilla area to accommodate the historic character of the Old City and tourists seeking an authentic, Orientalist Jerusalem. Architects condemned the proposal's obvious modernity, a blatant obstacle to the "unity" they earnestly sought with age-old East Jerusalem. In I972, Moshe Safdie, a member of the Jerusalem Committee, was commissioned to create a new plan for Mamilla.

Safdie proposed a megastructure built into the landscape, with major transportation facilities and several parking floors hidden beneath terraced gardens, part of a park leading from the Hinnom Valley to the Old City's walls. Projecting over major roads, the paved landing at the top of the park would lead eastward to the nearby Jaffa Gate, or westward to a sunken pedestrian path bisecting the terraced gardens and leading to Mamilla Street. The latter would turn into a pedestrian mall punctuated by several openings overlooking the majestic vistas of the Hinnom Valley and the Old City. An adjacent residential village and a major hotel would follow the contours of a vernacular Palestinian village. Incorporating open green 


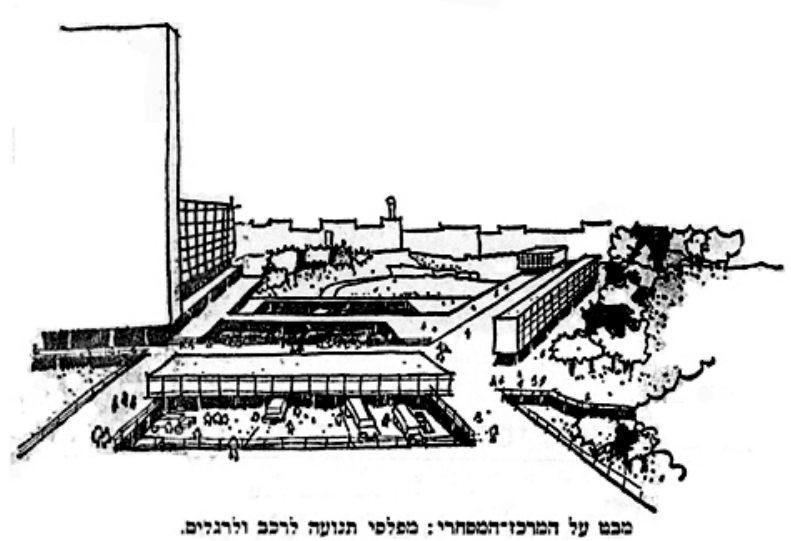

Michael Kuhn, Mamilla commercial center, I965.

spaces and a handful of existing buildings slated for preservation, this project disguised and thus suppressed the visually and politically problematic seam between old and new. ${ }^{6}$

The transition from Kuhn's Mamilla project to Safdie's exemplifies the evolution of the urban design debate in Jerusalem and its political implications. Kuhn conceptualized Mamilla as an extension of West Jerusalem's central business district. But the very modernity of his plan-its focus on efficiency, functionality, and profit, and its indifference to the character, forms, materials, spaces, and activities of the ancient city-caused its downfall after the city's unification. It was unfit for the story that Western critics and Israeli preservationists wanted Jerusalem's post-I967 "places" to tell about their past. The Jerusalem they desired was an Orientalist, place-bound city in a late-twentieth-century built landscape that would solve their anxieties about modernist cities. Seizing this opportunity for both their beautiful, sensual, beloved city, and their professional crisis, architects and planners accepted responsibilities of urban designers to mitigate the alienating forces of modernism, confirm their "visual idea" of Jerusalem, and tell the story of an antiquated, mysterious, symbolic, and pristine Jerusalem.

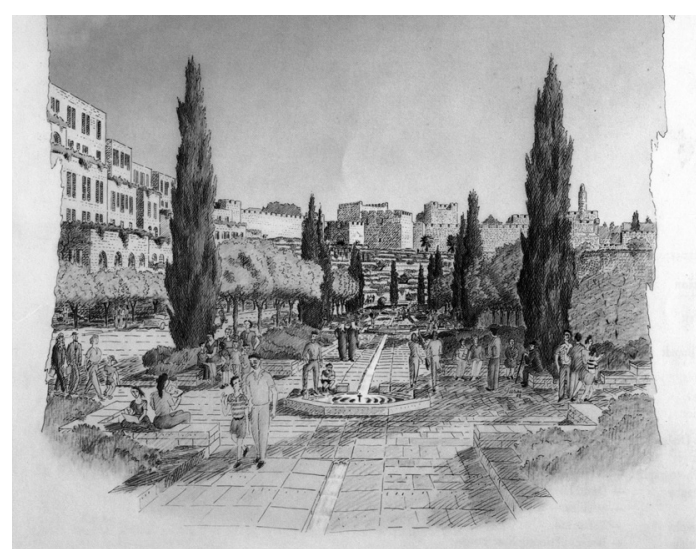

Moshe Safdie, Mamilla complex, I97os.

Who would be the ultimate narrator of Jerusalem's story? Mayor Teddy Kollek or the residents of the city, Jews and Arabs? The Jerusalem Committee or the Israeli government? The answer was neither simple nor clear. The government was interested primarily in territorial politics, the possession and demographic judaization of the Old City. Kollek was invested in cultural politics: legitimization of Israeli rule over the entire city by "beautifying" it, thus securing for the international community its "visual idea" of Jerusalem. Jewish residents desired functional urban infrastructure and symbolic connection to the city's Biblical past. Arab residents refused to participate in any planning debates as long as East Jerusalem was occupied - a condition they considered temporary.

After 1967, a return to colonial ideas about the city meant that one particular history would have to be chosen to guide contemporary town planning. Why was the Orientalist narrative chosen over more recent onesthose of the multicultural Ottoman Empire or the British Mandate, or the ruling Israeli state's?

The answer can be found in the words of the American architect Louis Kahn, who declared, at the Jerusalem Committee's first meeting, that "Jerusalem deserved the aura of the immeasurable."7 When he and his col- 
leagues arrived in Jerusalem, though, their search for its urban aura was already colored by their own Eurocentric concepts of Jerusalem as a "visual idea" expressing the city's virtuous spirituality. Urban design, which for Kahn was architecture at its best, was the means to give this idea an appropriate form. Introducing what Safdie called the "world of visual and aesthetic determinants," architects became complicit, indispensable agents in the "beautification of Jerusalem," the quintessence of Kollek's cultural politics. Safdie's Mamilla project exemplified this phenomenon. It attempted to situate East Jerusalem in modernity while confirming the relevance of its built forms, in-between spaces, and topography, and their overall relationship to the city's landscapes and contemporary architecture. Simultaneously, it helped Kollek maintain the Western world's traditional "visual idea" of Jerusalem.

This idea, however, had been formed far away in time and place and was given new life through the capacity of urban design to create character-imbued environments and transform them into new realities while the ideologies beneath them disappeared from sight. In Jerusalem, urban design articulated spatially that which politicians could not achieve politically. Nevertheless, after almost four decades of Jerusalem's "beautification" and the imminent completion of the Mamilla project, serious and disturbing questions remain. Can we really consider Safdie's "authentic" Mamilla any less an "urban renewal" project than Kuhn's? Does the urban center of the Holy City still belong to its Jewish, Christian, and Muslim residents? Do its everyday activities, memories and public events reflect its population? And does anyone - tourist or resident-feel truly at home in the New Jerusalem?
Moshe Safdie, "The New

Jerusalem: Planning and Politics," Book Review, Journal of the Society of Architectural Historians, 36:2

(May I977), pp.I30-I33.

2 Philip Johnson, "An Open Letter to Mayor Kollek," New York Times,

February 26, I97I.

3 Lewis Mumford to Teddy Kollek, December I970, quoted in Arthur

Kutcher, The New Jerusalem: Planning and Politics (London: Thames \&

Hudson, I973), p. 9.

4 The Government and the Jerusalem Municipality announced in 1965 a competition for the rehabilitation of what was then considered East Jerusalem, i.e., the area spanning from Mamilla in the North to Abu Tur in the South, and bounded by the City Walls to the East and King David Street to the West. Mamilla was the only area of the competition that was subjected to a massive erasure and new construction.

5 For both stages of the competition, the chair of the judges' panel was Ya'akov Rechter, and the mayor, Mordechai Ish-Shalom. See protocols of the competition, Stage II, for the planning of East Jerusalem (the public, conceptual competition for urban planning), p. 3 .

6 Moshe Safdie and Gilbert Weil, "Jerusalem Rehabilitation of the Jewish Quarter and the Mamila Project," Planning and Building Developments (I978), pp. 24-27.

7 Kahn in Abraham Rabinovich, "Planners under Fire," Jerusalem Post, December 25th, I970, P. 20 